\title{
THE EFFECT OF SAUROPUS ANDROGYNUS LEAVES EXTRACT PLUS TURMERIC POWDER ON FAT DEPOSITION, CARCASS QUALITY AND BLOOD PROFILE IN BROILERS FED LOW PROTEIN DIETS
}

\author{
U. Santoso, Kususiyah and Suharyanto \\ Department of Animal Science, Faculty of Agriculture, Bengkulu University, \\ Jalan Raya W. R. Supratman, Bengkulu - Indonesia \\ Corresponding E-mail : uripsantoso60@gmail.com
}

Received November 06, 2014; Accepted February 18, 2015

\begin{abstract}
ABSTRAK
Penelitian ini dirancang untuk mengevaluasi efektivitas suplementasi ekstrak daun katuk (EDK) plus tepung kunyit (TK) terhadap mutu karkas dan profil darah pada broiler yang diberi pakan berprotein rendah. Enam puluh broiler umur 14 hari dibagi ke dalam 5 kelompok perlakuan sebagai berikut: 1) Broiler diberi pakan berprotein 19\% tanpa suplementasi sebagai kontrol (P0); 2) Broiler diberi pakan berprotein 17\% yang disuplementasi dengan 4,5 g EDK/kg pakan plus 0,5\% TK; 3) Broiler diberi pakan berprotein $17 \%$ yang disuplementasi dengan $4,5 \mathrm{~g}$ EDK $/ \mathrm{kg}$ pakan plus $1 \% \mathrm{TK} ; 4$ ) Broiler diberi pakan berprotein $15 \%$ yang disuplementasi dengan $4,5 \mathrm{~g}$ EDK $/ \mathrm{kg}$ pakan plus $0,5 \% \mathrm{TK}$ dan; 5) Broiler diberi pakan berprotein $15 \%$ yang disuplementasi dengan $4,5 \mathrm{~g}$ EDK $/ \mathrm{kg}$ pakan plus $1 \% \mathrm{TK}$. Suplementasi EDK plus TK berpengaruh nyata $(\mathrm{P}<0,05)$ terhadap pertambahan berat badan, konsumsi pakan, konsumsi protein, cacat daging paha dan deposisi lemak. Tidak ditemukan pengaruh nyata $(\mathrm{P}>0,05)$ dari perlakuan terhadap bau karkas, warna shank, cacat dada, berat paha, berat dada $(\mathrm{P}>0,05)$, kadar kolesterol daging, fatty liver score dan toksisitas. Dapat disimpulkan bahwa suplementasi EDK plus TK pada pakan berprotein rendah tidak mampu menurunkan deposisi lemak, tetapi menurunkan konsentrasi asam urat dan meningkatkan konsentrasi glukosa dalam darah pada broiler.
\end{abstract}

Kata kunci: ekstrak daun katuk, tepung kunyit, deposisi lemak, broiler

\begin{abstract}
The present study was designed to evaluate the effectiveness of Sauropus androgynus leaves extract (SALE) plus turmeric powder (TP) on carcass quality and blood profile in broilers fed low protein diets. Sixty broilers aged 14 days were divided to 5 treatment groups as follows: 1) Broilers fed $19 \%$ protein diet without SALE plus TP as control (P0); 2) Broilers fed 17\% protein diet supplemented to $4.5 \mathrm{~g} \mathrm{SALE} / \mathrm{kg}$ diet plus $0.5 \% \mathrm{TP}(\mathrm{P} 1) ; 3)$ Broilers fed $17 \%$ protein diet supplemented to $4.5 \mathrm{~g}$ SALE/kg diet plus $1 \%$ TP (P2); 4) Broilers fed 15\% protein diet supplemented to $4.5 \mathrm{~g} \mathrm{SALE} / \mathrm{kg}$ diet plus $0.5 \% \mathrm{TP}(\mathrm{P} 3)$ and; 5) Broilers fed $15 \%$ protein diet supplemented to $4.5 \mathrm{~g}$ SALE $/ \mathrm{kg}$ diet plus $1 \%$ TP (P4). Supplementation of SALE plus TP significantly affected body weight gain, feed intake, protein intake, thigh meat haemorrhage and fat deposition $(\mathrm{P}<0.05)$. No significantly different was observed on carcass odor, shank color, breast meat haemorrhage, leg and breast weight, meat cholesterol, fatty liver score and tocixity $(\mathrm{P}>0.05)$. In conclusion suplementation of SALE plus TP had no beneficial effect on reducing fat deposition in broilers fed low protein diets, but it reduced blood uric acid but increased blood glucose concentration.
\end{abstract}

Keywords: Sauropus androgynus leaves extract, turmeric powder, fat position, broilers 


\section{INTRODUCTION}

Experimental investigation showed that feeding low protein diets to broilers reduced production cost and nitrogen pollution resulted from its excessive excretion (El-Hakim et al., 2009; Hernandez et al., 2012); reduced nitrogen convertion to ammonia; reduced heat stress (Furlan et al., 2004) and increased nitrogen utilization efficiency in poultry (El-Hakim et al., 2009; Parsons, 1995; Nahm, 2007). Schuttle et al. (1993) reported that the reduction of $1 \%$ nitrogen each in the diets would reduce nitrogen excretion as many as $10 \%$. Hernandez et al. (2012) found that the reduction of $1.5 \%$ or $3.0 \%$ protein content in diets would reduce nitrogen excretion as many as $9.5 \%$ or $17 \%$ in male broilers, and $11.8 \%$ or $14.6 \%$ in female broilers. However, feeding low protein diets increased fat deposition and fat contents of meat and carcass (Bunchasak et al., 1997; Farahdiba et al., 2011; Jlali et al., 2012; Labussiere et al., 2008: Pesti, 2009; Wood et al., 2004). A high fat content of broiler meat and carcass reduced market value, because recently consumers tended to consume low fat poultry products. It was known that consuming a high fat meat would increase risk of hypercholesterolemia, atherosclerosis, coronary heart disease, stroke and cancer occurences (Pal et al., 1999; Grundy dan Denke, 1990).

The disadvantage of feeding low protein diets should be balanced by feed additive supplementation which could inhibit fat deposition. Santoso et al. (2013) showed that supplementation of $4.5 \mathrm{~g}$ Sauropus androgynus leaves extract (SALE) to low protein diets could maintain fat level of broiler meat similar to control. It means that SALE could inhibit a high fat growth resulted from feeding low protein diets. However, it was known that broilers fed normal protein level diets still produced high fat broiler meats. Therefore, it might be benefit if SALE supplementaion is combined with another supplement to produce meat with lower fat content than the normal condition. One of the potential herbal is turmeric. Supplementation of 1 $\mathrm{g}$ turmeric powder (TP) per kg diet was proven to reduce abdominal fat deposition in broilers (Samarasinghe et al., 2003). Solichedi (2001) reported that $2 \% \mathrm{TP}$ supplementation to diets reduced abdominal fat deposition and meat cholesterol content in broilers. Napirah (2013) also reported that $1 \%$ turmeric supplementation tended to reduce meat fat and cholesterol content in quail. Yiu et al. (2011) turmeric supplementation increased cholesterol $7 \quad \alpha$ hydroxylase, hemeoxygenase 1 and low-density lipoprotein receptors.

On the basis of reason above, the present study was conducted to evaluate the effect of SALE plus TP supplementation on fat deposition in broilers fed low protein diets. It was hypotized that supplementation of SALE plus TP reduce fat deposition in broilers fed low protein diets.

\section{MATERIALS AND METHODS}

\section{Sauropus androgynus Leaves Extraction and Turmeric Powder}

Sauropus androgynus (katuk) leaves obtained from local market was extracted by the method of Santoso et al. (2010). Nutritional composition of Sauropus androgynus leaves extacted by ethanol $70 \%$, ethanol $95 \%$ and hexane were also observed. Turmeric was collected from local market, washed and dried under the sun for 5 days, dried, milled and stored.

\section{Animals}

This study used a one-day old mixed sex broilers obtained from commercial hatchery. From 1 to 14 days of age, supplemental heat was provided with a hanging heat lamp. Temperature was maintained at $32.5^{\circ} \mathrm{C}$ in the first week and gradually decreased at the second week. The broilers were reared on the litter pens in a house under continuous fluorescent lighting with feed and water available ad libitum. Experimental diets are presented in Table 1.

\section{Feeding Treatments}

SALE level resulted from previous study (Santoso et al., 2013) was used in the present study and combined with TP at various levels. Sixty broilers aged 14 days of age were divided to 5 treatment groups as follows: 1) Broilers fed $19 \%$ protein diet without SALE plus TP as control (P0); 2) Broilers fed $17 \%$ protein diet supplemented with $4.5 \mathrm{~g} \mathrm{SALE} / \mathrm{kg}$ diet plus $0.5 \%$ TP (P1); 3) Broilers fed $17 \%$ protein diet supplemented with $4.5 \mathrm{~g}$ SALE $/ \mathrm{kg}$ diet plus $1 \%$ $\mathrm{TP}(\mathrm{P} 2) ; 4)$ Broilers fed $15 \%$ protein diet supplemented with $4.5 \mathrm{~g} \mathrm{SALE} / \mathrm{kg}$ diet plus $0.5 \%$ TP (P3) and; 5) Broilers fed 15\% protein diet supplemented with $4.5 \mathrm{~g}$ SALE $/ \mathrm{kg}$ diet plus $1 \%$ TP (P4). Broilers were weighed weekly, whereas feed intakes were measured daily. Body weight gain, feed intake, protein intake and feed 
Table 1. Experimental Composition of Diets

\begin{tabular}{lrrrrr}
\hline \multicolumn{1}{c}{ Feedstuffs (\%) } & \multicolumn{1}{c}{ P0 } & \multicolumn{1}{c}{ P1 } & \multicolumn{1}{c}{ P2 } & \multicolumn{1}{c}{ P3 } & \multicolumn{1}{c}{ P4 } \\
\hline Yellow corn & 57.00 & 60.69 & 60.69 & 59.44 & 59.44 \\
Rice bran & 5.00 & 8.37 & 7.87 & 17.12 & 16.62 \\
Concentrate & 34.20 & 26.69 & 26.69 & 19.19 & 19.19 \\
Mineral mixture & 1.70 & 1.70 & 1.70 & 1.70 & 1.70 \\
Salt & 0.10 & 0.10 & 0.10 & 0.10 & 0.10 \\
Top mix & 0.50 & 0 & 0 & 0 & 0 \\
SALE & 0 & 0.45 & 0.45 & 0.45 & 0.45 \\
Turmeric powder & 0 & 0.50 & 1.00 & 0.50 & 1.00 \\
Oil & 1.50 & 1.50 & 1.50 & 1.50 & 1.50 \\
Protein (\%) & 19.35 & 17.13 & 17.13 & 15.06 & 15.06 \\
ME (kcal/kg) & 3155.60 & 3150.18 & 3150.18 & 3102.29 & 3102.29 \\
Ca (\%) & 1.51 & 1.31 & 1.31 & 1.11 & 1.11 \\
P (\%) & 0.86 & 0.81 & 0.81 & 0.81 & 0.81 \\
\hline
\end{tabular}

P0 $=$ Broilers fed $19 \%$ protein diet without Sauropus androgynus leaves extract (SALE) plus turmeric powder (TP); P1 = Broilers fed $17 \%$ protein diet supplemented with $4.5 \mathrm{~g} \mathrm{SALE} / \mathrm{kg}$ diet plus $0.5 \% \mathrm{TP} ; \mathrm{P} 2=$ Broilers fed $17 \%$ protein diet supplemented with $4.5 \mathrm{~g}$ SALE $/ \mathrm{kg}$ diet plus $1 \% \mathrm{TP}$; P3 = Broilers fed $15 \%$ protein diet supplemented with $4.5 \mathrm{~g}$ SALE $/ \mathrm{kg}$ diet plus $0.5 \% \mathrm{TP}$ and; P4 $=$ Broilers fed $15 \%$ protein diet supplemented with $4.5 \mathrm{~g} \mathrm{SALE} / \mathrm{kg}$ diet plus $1 \% \mathrm{TP}$.

efficiency were then calculated.

\section{Sampling and Laboratorium Analysis}

At the end of experiment ( 35 days of age), 4 broilers for each treatment group were selected based on body weight, slaughtered and internal organs were weighed. Blood collection was conducted before slaughering for glucose and uric acid concentration analysis. Leg meats were collected, weighed and then analyzed for cholesterol contents (AOAC, 1980). Haemorrhage in thigh and breast meats, and meat color were scored according to Institute for Animal Science and Health, Netherlands reference scale of 1-5; shank colors were scored by broiler color fan from 101-108; and fatty liver score was measured by comparing liver color with standard color from 1-5 (Santoso et al., 2013).

Hepatosomatic index (HIS) was calculated as follows: liver weight/body weight x $100 \%$, whereas viscerosomatic index (VSI) was calculated as follows: internal organ weight/body weight $\mathrm{x} 100 \%$ and toxicity was calculated as follows: (liver + spleen) weights/body weight $\mathrm{x}$ $100 \%$.

\section{Data Analysis}

All data were subjected to analysis of variance, and if there were significantly different they were then determined by Duncan's Multiple Range Test.

\section{RESULTS AND DISCUSSION}

\section{Nutritional Composition of SALE}

Proximate analysis of Sauropus androgynus leaves extracted by different solution are presented in Table 2. It was shown that ethanol $70 \%$ extract was rich in ash and protein but low in extract ether and nitrogen free extrcat (NFE). Ethanol $95 \%$ extract was rich in protein and extract ether but low in ash and NFE. Sauropus androgynus leaves extracted by hexane had low in ash and protein but high in extract ether and NFE. These three solutions resulted in similar content 
Table 2. Proximate Analysis of Sauropus androgynus Leaves Extract

\begin{tabular}{lccccccc}
\hline & Dry Matter & Ash & Protein & Crude Fiber & Ether Extract & NFE & Moisture \\
\hline Ethanol 70\%, \% & 83.05 & 8.76 & 24.14 & 10.04 & 12.16 & 27.95 & 16.95 \\
Ethanol 95\%, \% & 89.40 & 2.52 & 23.68 & 13.25 & 24.01 & 25.94 & 10.60 \\
Hexane, \% & 97.95 & 1.18 & 12.53 & 11.96 & 26.85 & 45.43 & 2.05 \\
\hline
\end{tabular}

NFE $=$ Nitrogen Free Extract

of crude fiber. In order to extract protein from Sauropus androgynus leaves ethanol was better than hexane.

\section{Performance of Broiler}

Effect of Sauropus androgynus leaves extract and turmeric podwer supplementation on performance of broilers fed low protein diets are presented in Table 3. Supplementation of SALE plus TP significant affected body weight gain $(\mathrm{P}<0.05)$. It was shown that $\mathrm{P} 4$ had lower body weight gain than $\mathrm{P} 0$ and $\mathrm{P} 1(\mathrm{P}<0.05)$, but it was similar to P2 and P3 ( $>0.05)$. Supplementation of SALE plus TP significantly affected feed intake and protein intake $(\mathrm{P}<0.05)$. It was shown that $\mathrm{P} 3$ and $\mathrm{P} 4$ had lower feed intake as compared to $\mathrm{P} 0$, $\mathrm{P} 1$ and P2. P3 and P4 had lower protein intake as compared to $\mathrm{P} 0$.

It was shown that supplementation SALE at level of 4.5 or $9 \mathrm{~g} / \mathrm{kg}$ plus $0.5 \%$ or $1 \%$ TP to $17 \%$ protein diet or supplementation $4.5 \mathrm{~g}$ SALE $/ \mathrm{kg}$ plus $0.5 \% \mathrm{TP}$ to $15 \%$ protein diet resulted in similar body weight gain as compared to $19 \%$ protein diet. Nuraini et al. (2014) found that supplementation of SALE to $17 \%$ protein diets resulted in similar body weight to $19 \%$ protein diet, but supplementation of SALE to $15 \%$ protein diets resulted in lower body weight gain. It was interested that in the present study showed that the combination of $4.5 \mathrm{~g} \mathrm{SALE} / \mathrm{kg}$ and $0.5 \% \mathrm{TP}$ resulted in similar body weight gain to $19 \%$ protein diet (control). It means that supplementation of $0.5 \%$ TP stimulated growth of broilers fed $15 \%$ protein diets. Hosseini-Vashan et al. (2012) reported that $0.8 \%$ TP supplementation tended to increase body weight in broilers under heat stress. Suvanated et al. (2003) reported that broilers under heat stress fed dietary turmeric powder had a higher body weight gain, energy efficiency ratio, yield of production and lower FCR than the basal diet. The present study was conducted in Bengkulu region which have temperatur range from $26^{\circ} \mathrm{C}$ to $34^{\circ} \mathrm{C}$ indicated that broilers might be reared under heat stress.

\section{Carcass Quality}

Effect of SALE plus TP supplementation on carcass quality of broilers fed low proteins diets are presented in Table 4. No significantly different was observed on carcass odor, shank color, haemorrhage in breast meat and leg weight $(\mathrm{P}>0.05)$. SALE plus TP supplementation significantly affected haemorrhage in thigh. It was shown that P2, P3 and P4 had lower score of haemorrhage in thigh as compared with $\mathrm{P} 0$ and P1, whereas P1 had lower score than P0. Similar results was reported by Santoso et al. (2013) who found that SALE supplementation reduced haemorrhage in thigh meat. Sauropus androgynus leaves is rich in flavonoids and antioxidants (Andarwulan et al., 2010), and antiinflammantory (Selvi and Bhascar, 2012). These factors were predicted to play a role in the reduction of haemorrhages in thigh meat. In addition, turmeric powder supplementation might also contribute to this phenomenon, since turmeric exhibit anti-inflammatory, anti-human immunodeficiency virus, anti-bacteria, antioxidant effects and nematocidal activities (Araujo and Leon, 2001).

Sauropus androgynus leaves is rich in iron, i.e. $2.7 \mathrm{mg} / 100 \mathrm{~g}$ of fresh leaves (Wiradimadja et al., 2006), but it did not improve the color of broiler meats. This result was in agreement with Santoso et al. (2013) finding who reported that supplementation of SALE did not increase the color of broiler meats. In addition, turmeric supplementation had also no beneficial effect on increasing meat color.

Although shank color was not significantly different, the value of $\mathrm{P} 2$ and $\mathrm{P} 4$ had higher shank color as compared to the control. Therefore, 
Table 3. Effect of Sauropus androgynus Leaves Extract and Turmeric Powder Supplementation on Performance of Broilers Fed Low Protein Diets

\begin{tabular}{lcccccc}
\hline \multicolumn{1}{c}{ Variable } & P0 & P1 & P2 & P3 & P4 & SD \\
\hline Weight gain, g/bird/day & $74.4^{\mathrm{b}}$ & $72.2^{\mathrm{b}}$ & $69.8^{\mathrm{ab}}$ & $70.0^{\mathrm{ab}}$ & $59.6^{\mathrm{a}}$ & 26.2 \\
Feed intake, g/bird/day & $157.3^{\mathrm{b}}$ & $146.8^{\mathrm{b}}$ & $156.3^{\mathrm{b}}$ & $120.6^{\mathrm{a}}$ & $137.0^{\mathrm{a}}$ & 20.0 \\
Protein intake, g/bird/day & $30.4^{\mathrm{b}}$ & $25.2^{\mathrm{ab}}$ & $26.8^{\mathrm{ab}}$ & $18.2^{\mathrm{a}}$ & $20.6^{\mathrm{a}}$ & 3.9 \\
Feed efficiency, \% & 47.3 & 49.2 & 44.7 & 58.0 & $43.5^{\mathrm{ns}}$ & 6.5 \\
\hline
\end{tabular}

$\mathrm{SD}=$ standard deviation; $\mathrm{P} 0=$ Broilers fed $19 \%$ protein diet without Sauropus androgynus leaves extract (SALE) plus turmeric powder (TP); P1 = Broilers fed $17 \%$ protein diet supplemented with $4.5 \mathrm{~g}$ SALE $/ \mathrm{kg}$ diet plus $0.5 \%$ TP; P2 = Broilers fed $17 \%$ protein diet supplemented with $4.5 \mathrm{~g}$ SALE $/ \mathrm{kg}$ diet plus $1 \% \mathrm{TP}$; P3 $=$ Broilers fed $15 \%$ protein diet supplemented with $4.5 \mathrm{~g} \mathrm{SALE} / \mathrm{kg}$ diet plus $0.5 \% \mathrm{TP}$ and; P4 = Broilers fed $15 \%$ protein diet supplemented with $4.5 \mathrm{~g} \mathrm{SALE} / \mathrm{kg}$ diet plus $1 \% \mathrm{TP}$.

Table 4. Effect of Sauropus andogynus Leaves Extract and Turmeric Powder Supplementation on Carcass Quality of Broilers Fed Low Protein Diets

\begin{tabular}{lcccccc}
\hline \multicolumn{1}{c}{ Variable } & P0 & P1 & P2 & P3 & P4 & SD \\
\hline Carcass odor & 3.5 & 2.81 & 3.38 & 2.75 & $3.31^{\mathrm{ns}}$ & 0.72 \\
Shank color score & 102.3 & 102.3 & 103.0 & 102.0 & $103.5^{\mathrm{ns}}$ & 0,88 \\
Haemorrhage in thigh & $3.25^{\mathrm{c}}$ & $2.00^{\mathrm{b}}$ & $1.56^{\mathrm{a}}$ & $1.63^{\mathrm{a}}$ & $1.50^{\mathrm{a}}$ & 1.06 \\
Haemorrhage in breast & 2.06 & 1.63 & 1.56 & 1.50 & $1.50^{\mathrm{ns}}$ & 0,35 \\
Left leg weight, \% BW & 10.76 & 9.99 & 10.16 & 10.26 & $10.58^{\mathrm{ns}}$ & 0,88 \\
Right leg weight, \% BW & 10.36 & 10.62 & 10.43 & 10.79 & $10.39^{\mathrm{ns}}$ & 0.85 \\
Left breast weight, \% BW & 11.77 & 10.67 & 11.25 & 10.01 & $10.96^{\mathrm{ns}}$ & 0.75 \\
Right breast weight, \% BW & 11.56 & 10.12 & 11.05 & 9.98 & $9.95^{\mathrm{ns}}$ & 0.70 \\
Meat color score & 2.63 & 2.38 & 2.13 & 2.00 & $2.38^{\mathrm{ns}}$ & 0.43 \\
\hline
\end{tabular}

$\mathrm{SD}=$ standard deviation; $\mathrm{P} 0=$ Broilers fed $19 \%$ protein diet without Sauropus androgynus leaves extract (SALE) plus turmeric powder (TP); P1 = Broilers fed $17 \%$ protein diet supplemented with $4.5 \mathrm{~g}$ SALE $/ \mathrm{kg}$ diet plus $0.5 \%$ TP; $\mathrm{P} 2=$ Broilers fed $17 \%$ protein diet supplemented with $4.5 \mathrm{~g} \mathrm{SALE} / \mathrm{kg}$ diet plus $1 \% \mathrm{TP} ; \mathrm{P} 3$ $=$ Broilers fed $15 \%$ protein diet supplemented with $4.5 \mathrm{~g} \mathrm{SALE} / \mathrm{kg}$ diet plus $0.5 \% \mathrm{TP}$ and; $\mathrm{P} 4=$ Broilers fed $15 \%$ protein diet supplemented with $4.5 \mathrm{~g} \mathrm{SALE} / \mathrm{kg}$ diet plus $1 \% \mathrm{TP}$.

although Sauropus androgynus leaves had high level of $\beta$-carotene (Hulshof et al.,1997), supplementation of SALE at level of $4.5 \mathrm{~g}$ SALE/kg diets was not addequate to induce shank color. This SALE level will induce shank color if SALE is combined with $1 \%$ TP. It means that turmeric powder had significant contribution on shank color.

No change in carcass odor was in agreement with Santoso et al. (2013) observation who found that SALE supplementation did not reduce carcass odor. Therefore, this result showed no beneficial effect of turmeric powder on reducing carcass odor.

\section{Fat Deposition, Blood, Uric Acid and Glucose Concentration}

Effect of Sauropus androgynus leaves extract and turmeric powder suppelementation on total fat deposition, meat cholesterol, fatty liver score, 
Table 5. Effect of Sauropus andogynus Leaves Extract and Turmeric Powder Supplementation on Total Fat Deposition, Meat Cholesterol, Fatty Liver Score, Serum Glucose and Uric Acid Concentration in Broilers Fed Low Protein Diets

\begin{tabular}{lcccccc}
\hline \multicolumn{1}{c}{ Variable } & P0 & P1 & P2 & P3 & P4 & SD \\
\hline Total fat deposition, \% BW & $2.14^{\mathrm{a}}$ & $2.46^{\mathrm{ab}}$ & $3.22^{\mathrm{b}}$ & $3.35^{\mathrm{b}}$ & $3.59^{\mathrm{b}}$ & 0.75 \\
Meat cholesterol, mg/100 mg & 0.68 & 0.64 & 0.66 & 0.66 & $0.65^{\mathrm{ns}}$ & 0.05 \\
Fatty liver score & 2.56 & 2.56 & 2.44 & 2.31 & $2.63^{\mathrm{ns}}$ & 0.33 \\
Glucose,mg/dl & $196.00^{\mathrm{b}}$ & $194.00^{\mathrm{b}}$ & $137.00^{\mathrm{a}}$ & $254.00^{\mathrm{c}}$ & $231.00^{\mathrm{c}}$ & 40.46 \\
Uric acid, mg/dl & 6.50 & 4.40 & 3.30 & Low & Low & -
\end{tabular}

$\mathrm{SD}=$ standard deviation; $\mathrm{P} 0=$ Broilers fed $19 \%$ protein diet without Sauropus androgynus leaves extract (SALE) plus turmeric powder (TP); P1 = Broilers fed 17\% protein diet supplemented with $4.5 \mathrm{~g}$ SALE $/ \mathrm{kg}$ diet plus $0.5 \% \mathrm{TP}$; P2 = Broilers fed $17 \%$ protein diet supplemented with $4.5 \mathrm{~g}$ SALE $/ \mathrm{kg}$ diet plus $1 \% \mathrm{TP}$; P3 = Broilers fed 15\% protein diet supplemented with $4.5 \mathrm{~g}$ SALE $/ \mathrm{kg}$ diet plus $0.5 \% \mathrm{TP}$ and; $\mathrm{P} 4=$ Broilers fed $15 \%$ protein diet supplemented with $4.5 \mathrm{~g}$ SALE $/ \mathrm{kg}$ diet plus $1 \% \mathrm{TP}$.

serum glucose and uric acid concentrations in broilers fed low protein diets are presented Table 5. Supplementation of SALE plus TP to low protein diets significantly affected fat deposition $(\mathrm{P}<0.05)$, but it had no effect on meat cholesterol and fatty liver score $(\mathrm{P}>0.05)$. It was shown that P0 had lower fat deposition as compared with P2, P3 and $\mathrm{P} 4(\mathrm{P}<0.05)$ but it was similar to $\mathrm{P} 1$ $(\mathrm{P}>0.05)$.

A higher fat deposition in broiler chicken fed low protein diet showed that supplementation SALE plus TP failed to inhibit rapid fat deposition as a result of feeding low protein diets. The present study was in contrary with the observation Santoso et al. (2013) who found that SALE supplementation inhibit fat deposition in broiler fed low protein diets, and therefore fat deposition was similar to broilers fed normal protein diets. This difference might be caused by difference of slaughtered age where in the previous study broilers were slaughtered at 42 days of age whereas in the present study was slaughtered at 35 days age. It was unkown why TP could not inhibit fat deposition as a result of feeding low protein diets. SALE and TP might have antagonist compounds and therefore they failed to reduce fat deposition in broilers fed low protein diets.

SALE plus TP supplementation could inhibit rapid cholesterol deposition as a result of feeding low protein diets although its content was still similar to the control (broiler chicken fed 19\% protein diets). Santoso et al. (2013) reported that supplementation of $4.5 \mathrm{~g}$ SALE $/ \mathrm{kg}$ diet resulted in similar meat cholesterol content to the control. Therefore, TP supplementation at level of $0.5 \%$ or $1 \%$ could not reduce meat cholesterol content further.

The concentrations of blood glucose for $\mathrm{P} 0$, $\mathrm{P} 1, \mathrm{P} 2, \mathrm{P} 3$ or $\mathrm{P} 4$ were $196 \mathrm{mg} / \mathrm{dl}, 194 \mathrm{mg} / \mathrm{dl}, 137$ $\mathrm{mg} / \mathrm{dl}, 254 \mathrm{mg} / \mathrm{dl}$ or $231 \mathrm{mg} / \mathrm{dl}$, whereas the concentration of blood uric acid for P0, P1, P2, P3 or P4 were $6,5 \mathrm{mg} / \mathrm{dl}, 4,4 \mathrm{mg} / \mathrm{dl}, 3,3 \mathrm{mg} / \mathrm{dl}$, low or low, respectively (Table 5). Thus, feeding low protein diets reduced blood uric acid, and higher turmeric powder supplementation might also reduce it. Lower blood uric acid concentration might indicate lower nitrogen excretion and therefore reduce nitrogen pollution. This asumption was in agreement with the observation of Schuttle et al. (1993) and Hernandez et al. (2012) who found that feeding low protein diet reduced nitrogen excretion. Low protein diet reduced both plasma ammonia (Okumura and Tasaki, 1969) and ucid acid (Karasawa et al., 1973; Okumura and Tasaki, 1969) in chickens. Lower blood uric acid was in agreement with Namroud et al. (2008) who found that feeding low protein diet resulted in lower plasma uric acid in broiler chicks. Furthermore, they reported that feeding low protein diet reduced nitrogen and uric acid contents in excreta. Gowda et al. (2008) found than inclusion of $0.5 \%$ turmeric powder tended to reduce serum uric acid (from $6.2 \mathrm{mg} / \mathrm{dl}$ to $5.8 \mathrm{mg} / \mathrm{dl}$ ) in broilers. Kumari et al. (2007) also found that supplementation of turmeric powder (1 $\mathrm{g} / \mathrm{kg}$ diet) reduced serum uric acid concentration 
(from $6.31 \mathrm{mg} / \mathrm{dl}$ to $4.21 \mathrm{mg} / \mathrm{dl}$ ) in broilers. It is a well documented that uric acid constitutes $60-80$ $\%$ of total nitrogen in the urine of the birds. In birds it is synthesized in liver as well as kidney. Uric acid of birds is not catalyzed into allentoin, like mammals, due to absence of necessary enzyme like uricase (Kumari et al., 2007).

It was unkown why low protein diets increased blood glucose concentration, and suplementation of $1 \%$ turmeric powder had lower glucose concentration than that of $0.5 \%$ turmeric powder. Feeding low protein diet might reduce glucose catabolism related hormon such as insulin. Hada et al. (2013) found that broilers fed low protein presented lower body weight, feed intake, and worse feed conversion ratio on day 42 , as well as lower carcass and breast yields, higher leg and abdominal fat yields, higher triglyceride and lower uric acid blood levels (Hada et al., 2013), but had no effect on blood glucose concentration. Gannon et al. (2003) found that low protein diet resulted in higher blood glucose concentration in persons with type 2 diabetes. It was unkown why higher turmeric powder resulted in lower blood glucose concentration. Klemens (2006) stated that turmeric may decrease blood sugar levels. The apparent blocking of enzymes that convert dietary carbohydrates into glucose may be involved in this lowing of blood sugar. Kumar and Salimath (2014) reported that supplementation turmeric extract reduced blood glucose concentration in streptozotocin-induced diabetic rats.

\section{Internal Organ Weight}

Effect of Sauropus androgynus leaves extract and turmeric powder on internal organ weights and toxicity in broilers fed low protein diets are presented in Table 6. It was shown that supplementation Sauropus androgynus extract plus turmeric powder had no effect on HIS, heart, spleen, gizzard, intestine, pankreas, shank, VIS, intestine length and toxisity. These data indicated that supplementation SALE plus TP to low protein diets had no negative effect on the function of internal organs. The present study was in agreement with the observation of Santoso et al. (2013) who found that SALE supplementation did not cause toxicity. In addition, Araujo and Leon (2001) reported that Curcuma longa L. (Zingiberaceae) exhibited anti-inflammatory, antihuman immunodeficiency virus, anti-bacteria,

Table 6. Effect of Sauropus andogynus Leaves Extract and Turmeric Powder Supplementation on Internal Organ Weights and Toxicity in Broilers Fed Low Protein Diets

\begin{tabular}{lllllll}
\hline Variables (\%BW) & P0 & P1 & P2 & P3 & P4 & SD \\
\hline HIS & 2.72 & 2.33 & 2.57 & 2.34 & $2.10^{\mathrm{ns}}$ & 0.41 \\
Heart & 0.55 & 0.48 & 0.50 & 0.60 & $0.67^{\mathrm{ns}}$ & 0.09 \\
Spleen & 0.22 & 0.25 & 0.22 & 0.29 & $0.16^{\mathrm{ns}}$ & 0.10 \\
Gizzard & 1.92 & 1.77 & 1.94 & 2.11 & $1.98^{\mathrm{ns}}$ & 0.30 \\
Intestine & 2.61 & 2.50 & 2.69 & 3.00 & $2.97^{\mathrm{ns}}$ & 0.32 \\
Intestine length & 11.63 & 10.92 & 12.10 & 13.66 & $13.34^{\mathrm{ns}}$ & 1.54 \\
Pankreas & 0.29 & 0.27 & 0.33 & 0.33 & $0.33^{\mathrm{ns}}$ & 0.06 \\
Shank & 3.53 & 3.50 & 3.87 & 3.96 & $4.02^{\mathrm{ns}}$ & 0.36 \\
VSI & 8.31 & 7.60 & 8.26 & 8.66 & $8.21^{\mathrm{ns}}$ & 0.58 \\
Toxicity & 2.94 & 2.58 & 2.79 & 2.63 & $2.26^{\mathrm{ns}}$ & 0.45 \\
\hline
\end{tabular}

HIS = hepatosomatic index; VSI = viscerosomatic index; SD = standard deviation; P0 = Broilers fed 19\% protein diet without Sauropus androgynus leaves extract (SALE) plus turmeric powder (TP); P1 = Broilers fed $17 \%$ protein diet supplemented with $4.5 \mathrm{~g}$ SALE $/ \mathrm{kg}$ diet plus $0.5 \% \mathrm{TP} ; \mathrm{P} 2=$ Broilers fed $17 \%$ protein diet supplemented with $4.5 \mathrm{~g}$ SALE $/ \mathrm{kg}$ diet plus $1 \% \mathrm{TP}$; $\mathrm{P} 3=$ Broilers fed $15 \%$ protein diet supplemented with $4.5 \mathrm{~g} \mathrm{SALE} / \mathrm{kg}$ diet plus $0.5 \% \mathrm{TP}$ and; P4 = Broilers fed $15 \%$ protein diet supplemented with $4.5 \mathrm{~g}$ $\mathrm{SALE} / \mathrm{kg}$ diet plus $1 \% \mathrm{TP}$. 
antioxidant effects and nematocidal activities. Curcumin is a major component in Curcuma longa L. being responsible for its biological actions. In vitro, curcumin exhibited antiparasitic, antispasmodic, anti-inflammatory and gastrointestinal effects; and also inhibited carcinogenesis and cancer growth. In vivo, curcumin showed the antiparasitic and antiinflammatory properties.

\section{CONCLUSION}

Supplementation of SALE plus TP did not reduce fat deposition in broilers fed low protein diets. Supplementation of SALE plus TP reduced blood uric acid but increased blood glucose concentration.

\section{ACKNOWLEDGMENT}

Researchers would like to thank the University of Bengkulu which has given research grants through the PNBP Grant Research under contract number 555/UN30.15/LT/2014 dated May 7, 2014.

\section{REFERENCES}

Andarwulan, N., R. Batari, D.A. Sandrasari, B. Bolling and H. Wijaya. 2010. Flavonoid content and antioxidant activity of vegetables from Indonesia. Food Chem. 121:1231-1235

AOAC. 1980. Official Methods of Analysis. 13th ed. Washington, Association of Official Analytical Chemists.

Araujo, C.A.C and L.L Leon. 2001. Biological Activities of Curcuma longa L. Mem. Inst. Oswaldo Cruz., Rio de Janeiro 96(5):723728

Bunchasak, C., U. Santoso, K. Tanaka, S. Ohtani and C.M. Collado. 1997. The effect of supplementing methionine plus cystine to low protein diet on the growth performance and fat accumulation of growing broilers. Asian-Aust. J. Anim. Sci. 10: 185-191

El-Hakim, Abd A.S., G. Cherian and M.N. Ali. 2009. Use of organic acid, herbs and their combination to improve the utilization of commercial low protein broiler diets. Int. J. Poult. Sci. 8:14-20

Farahdiba, U. Santoso and Kususiyah. 2011. Pengaruh aras protein dan ragi tape terhadap kualitas karkas dan deposisi lemak pada ayam broiler. Jurnal Sain Peternakan Indonesia 6:47-54

Furlan, R.L., F. Fiko De de, P.S. Rosa and M. Macari. 2004. Does low-protein diet improve broiler performance under heat stress condition? Brazilian J. Poult. Sci. 6:71-79

Gannon, M.C., F.Q. Nuttall, A. Saeed, K. Jordan and H. Hoover. 2003. An increase in dietary protein improves the blood glucose response in persons with type 2 diabetes. Am. J. Clin. Nutr. 78:734-41

Gowda, N.K.S., D.R. Ledoux, G.E. Rottinghaus, A.J. Bermudez and Y.C. Chen. 2008. Efficacy of turmeric (Curcuma longa), containing a known level of curcumin, and a hydrated sodium calcium aluminosilicate to ameliorate the adverse effects of aflatoxin in broiler chicks. Poult. Sci. 87:1125-1130

Grundy, S.M. and M.A. Denke. 1990. Dietary influences on plasma lipids and lipoproteins. J. Lipid Res. 31:1149-1172

Hada, F.H., R.D. Malheiro, J.D.T. Silva, R.H. Marques, R.A. Gravena, V.K. Silva and V.M.B. Moraes. 2013. Effect of protein, carbohydrate, lipid, and selenium levels on the performance, carcass yield, and blood changes in broilers. Rev. Bras. Cienc. Avic. 15:385-394

Hernandez, E., M. Lopez, S. Martinez, M.D. Megias, P. Catala and J. Madrid. 2012. Effect of low-protein diets and single sex on production performance, plasma metabolites, digestibility, and nitrogen excretion in 1- to 48-day-old broilers. Poult. Sci. 91:683-692

Hosseini-Vashan, S.J., A. Golian, A.Yaghobfar, A. Zarban, N. Afzali and P. Esmaeilinasab. 2012. Antioxidant status, immune system, blood metabolites and carcass characteristic of broilers fed turmeric rhizome powder under heat stress. African J. Biotech. 11: 16118-16125

Hulshof, P.J.M, C. Xu, P. van de Bovenkamp, Muhilal and C.E. West. 1997. Application of a validated method for the determination of provitamin A carotenoids in Indonesian foods of different maturity and origin. J. Agric. Food Chem. 45:1174-1179

Jlali, M. M.V. Gigaud, S. MétayerCoustard, N. Sellier, S. Tesseraud, E. Le Bihan-Duval and C. Berri. 2012. Modulation of glycogen and breast meat processing ability by nutrition in chickens: Effect of crude protein level in 2 
chicken genotypes. J. Anim. Sci.. 90:447455

Karasawa, Y., I. Tasaki, H.O. Yokota and F. Shibata. 1973. Effect of infused glutamine on uric acid synthesis in chickens fed high and low protein diets. J. Nutr. 103: 526-529.

Klemens, J. 2006. Herbs that lower blood sugar. JAAIM-Online. Page 1-5. http://www. aaimedicine.com/jaaim/sep06/BloodSugar.p df

Kumar, G.S. and P.V. Salimath. 2014. Effect of spent turmeric on kidney glycoconjugates in streptozotocin-induced diabetic rats. Journal of Diabetes \& Metabolic Disorders. 13:78

Kumari, P., M.K. Gupta, R. Ranjan, K.K.Singh and R. Yadava.2007. Curcuma longa as feed additive in broiler birds and its pathophysiological effects. Indian J. Exp. Biol. 45:272-277

Labussiere, E., S. Dubois, J. Van Milgen, G. Bertrand and J. Noblet. 2008. Effects of dietary crude protein on protein and fat deposition in milk-fed veal calves. J. Dairy Sci. 91:4741-4754

Nahm, K.H. 2007. Feed formulation to reduce N excretion and ammonia emisssion from poultry manure. Bioresour. Technol. 98: 2282-2300.

Namroud, N.F., M. Shivazad and M. Zaghari. 2008. Effects of fortifying low crude protein diet with crystalline amino acids on performance, blood ammonia level, and excreta characteristics of broiler chicks. Poult. Sci. 87:2250-2258

Napirah, A. 2013. Pengaruh Penambahan Tepung Kunyit (Curcuma domestica Valet) dalam Pakan Puyuh (Cortunic-cortunic japonica) Pedaging terhadap Performans, Profil Darah, Kandungan Lemak dan Kolesterol Daging Puyuh. Disertasi. Universitas Gajah Mada, Yogyakarta.

Nuraini, E., Warnoto and U. Santoso. 2014. Pengaruh level protein dan level suplementasi ekstrak daun katuk (Sauropus androgynus) terhadap performa broiler. Jurnal Sain Peternakan Indonesia 9:13-22

Okumura, J.I. and I. Tasaki. 1969. Effect of fasting, refeeding, and dietary protein level on uric acid and ammonia content of blood, liver and kidney in chickens. J. Nutr. 97: 316-320

Pal, S., C. Bursill, C.D.K. Bottema and P.D. Roach. 1999. Regulation of the low-density lipoprotein receptor by antioxidants. In:
Antioxidants in Human Helath and Disease. T. K. Basu, N. J. Temple and M. L. Garg (Eds.). CABI Publishing, New York. P:5570.

Parsons, C.M. 1995. Nutrient utilization and methods of assessment an environmental perspective, In: Deagussa Technical Symposium, pp: 1-5.

Pesti, G.M. 2009. Impact of dietary amino acid and crude protein levels in broiler feeds on biological performance. J. Appl. Poult. Res.18:477-486

Samarasingle, K., C. Wenk, K.F.S.T. Silva and J.M.D.M. Gunasekera. 2003. Turmeric (Curcuma longa) root powder and mannanoligosaccharides as alternatives to antibiotics in broiler chicken diets. AsianAust. J. Anim. Sci. 16: 1495-1500.

Santoso, U., Kususiyah and Y. Fenita. 2010. The effect of Sauropus androgynus extract and lemuru oil on fat deposition and fafty acid composition of meat in broilers. J.Indonesian Trop. Anim. Agric. 35:48-54

Santoso, U., Kususiyah and Y. Fenita. 2013. Effect of Sauropus androgynus leaves extract in fat deposition in broilers fed low containing diets. J.Indonesian Trop. Anim. Agric. 38:176-184

Schutte, J.B., J. de Jong and J.M. van Kempen. 1993. Dietary protein in relation to requirement and pollution in pigs during the body weight range $20-40 \mathrm{~kg}$. In: Pig Production and Environmental Consequences. Pudoc. Scientific Publisher, Wegeningen. The Netherlands. Pp. 259-263.

Selvi, S.V. and A. Bhaskar. 2012. Antiinflammatory and analgesic activities of the Sauropus androgynous (L) Merr. (Euphorbiaceae) Plant in experimental animal models. Der Pharmacia Lettre 4:782785 . http:scholarresearchlibrary.com/DPLvol4-iss3/DPL-2012-4-4-782-785.pdf.

Solichedi, K. 2001. Pemanfaatan Kunyit (Curcuma domestica VAL) dalam Ransum Broiler sebagai Upaya Menurunkan Lemak Abdominal dan Kadar Kolesterol. Thesis. Universitas Diponegoro, Semarang.

Suvanated C., S. Kijparkorn, K. Angkanaporn. 2003. Effect of turmeric (Curcuma longa linn.) as an antioxidant on immune status and growth performances of stressed broilers. Faculty of Veterinary Science, The Chulalongkorn University.

Wiradimadja, R., H. Burhanuddin dan D. 
Saefulhadjar. 2006. Peningkatan kadar vitamin A pada telur ayam melalui penggunaan daun katuk (Sauropus androgynus L.Merr) dalam ransum. Jurnal Ilmu Ternak. 6:28-31

Wood, J.D., G.R. Nute, R.I. Richardson, F.M. Whittington, O.G. Southwood, G. Plastow, R. Monsbridge, N. da Costa and K.C. Chang. 2004. Effects of breed, diet and muscle on fat deposition and eating quality in pigs. Meat Sci. 67: 651-667

Yiu, W.F., P.L. Kwan, C.Y. Wong, T.S Kam, S.M. Chiu, S.W. Chan and R. Chan. 2011. Attenuation of fatty liver and prevention of hypercholesterolemia by extract of Curcuma longa through regulating the expression of CYP7A1, LDL-Receptor, HO-1, and HMGCoA Reductase. J. Food Sci. 76:H80-H89. 